\title{
Excessive dietary lead reduces growth performance and increases lead accumulation in pigs
}

\author{
Hyunjun Choi ${ }^{1, a}$, Sang Yun $\mathrm{Ji}^{2, a}$, Hyunwoong $\mathrm{Jo}^{1}$, Minho Song ${ }^{3}$, and Beob Gyun Kim ${ }^{1, *}$
}

\author{
* Corresponding Author: Beob Gyun Kim \\ Tel: +82-2-2049-6255, Fax: +82-2-455-1044, \\ E-mail: bgkim@konkuk.ac.kr \\ ${ }^{1}$ Department of Animal Science and \\ Technology, Konkuk University, Seoul 05029, \\ Korea \\ ${ }^{2}$ Animal Nutritional Physiology Team, \\ National Institute of Animal Science, Rural \\ Development Administration, Wanju 55365, \\ Korea \\ ${ }^{3}$ Department of Animal Science and \\ Biotechnology, Chungnam National \\ University, Daejeon 305764, Korea \\ a These authors contributed equally to this \\ work. \\ ORCID \\ Hyunjun Choi \\ https://orcid.org/0000-0002-5874-2328 \\ Sang Yun Ji \\ https://orcid.org/0000-0001-7235-3655 \\ Hyunwoong Jo \\ https://orcid.org/0000-0002-3837-6041 \\ Minho Song \\ https://orcid.org/0000-0002-4515-5212 \\ Beob Gyun Kim \\ https://orcid.org/0000-0003-2097-717X
}

Submitted Apr 10, 2020; Revised May 20, 2020; Accepted Jun 26, 2020
Objective: The objective of this study was to investigate the influence of dietary lead $(\mathrm{Pb})$ supplementation and feeding period on growth performance, organ weight, and $\mathrm{Pb}$ accumulation in pigs.

Methods: In a 56-day feeding experiment, a total of 48 barrows with initial body weight $10.4 \pm 0.6 \mathrm{~kg}$ were allotted to 2 dietary treatments $(0$ and $200 \mathrm{mg} / \mathrm{kg}$ of supplemental $\mathrm{Pb}$ ) in a completely randomized design with 6 replicates. Body weight and feed intake were recorded to calculate growth performance. At the end of each 14 day-period (on days $14,28,42$, and 56), an animal was randomly selected from each pen and slaughtered to collect blood samples, hair samples, left 5th rib, heart, liver, kidneys, lungs, and longissimus dorsi muscle samples.

Results: Average daily gain and average daily feed intake were reduced $(\mathrm{p}<0.05)$ by supplemental $\mathrm{Pb}$ during the day 42 to 56 . Relative kidney weight to body weight was linearly increased with increasing feeding period in pigs fed the $\mathrm{Pb}$-supplemented diet, but not in pigs fed the control diet $(\mathrm{p}<0.05)$. The $\mathrm{Pb}$ concentrations in hair, left 5 th rib, kidneys, and lungs were linearly increased with longer feeding period in pigs fed the $\mathrm{Pb}$-supplemented diet, but not in pigs fed the control diet $(\mathrm{p}<0.01)$.

Conclusion: Dietary $\mathrm{Pb}$ supplementation caused growth retardation and $\mathrm{Pb}$ accumulation in most organs, particularly in hair, bone, and kidneys in a time-dependent manner.

Keywords: Exposure Time; Lead Accumulation; Organ; Swine; Tissue; Toxicity

\section{INTRODUCTION}

Contamination of heavy metals in animal feeds is a problem in animal production and health. Among heavy metals, lead $(\mathrm{Pb})$ exposure in domestic animals due to environmental pollution has been often reported [1]. Contamination of $\mathrm{Pb}$ in animal feeds is the major route of $\mathrm{Pb}$ exposure in domestic animals [2]. Lead, even at a relatively low concentration, can cause various damages to animals such as poisoning and growth retardation $[3,4]$. In animals fed with a $\mathrm{Pb}$-contaminated diet, $\mathrm{Pb}$ is mainly absorbed through the gastrointestinal tract and accumulated in bone, liver, kidneys, and hair $[5,6]$. The $\mathrm{Pb}$ concentration in a complete diet should not exceed $10 \mathrm{mg} / \mathrm{kg}$ in the Republic of Korea, $30 \mathrm{mg} / \mathrm{kg}$ in the United States [7] and less than $5 \mathrm{mg} / \mathrm{kg}$ in the Europe Union [8]. In addition, $\mathrm{Pb}$ accumulated in organs and tissues of animals could be exposed to humans through the food chain [2].

$\mathrm{The} \mathrm{Pb}$ concentrations in organs and tissues are known to be increased with increasing exposure time or $\mathrm{Pb}$ concentration in animal feeds [5]. In addition, $\mathrm{Pb}$ can accumulate more in young animals than in old ones $[9,10]$. However, very limited information is available on dietary $\mathrm{Pb}$ toxicity in nursery pigs and on the influence of feeding period of $\mathrm{Pb}$-containing diets to young pigs. Feeding $\mathrm{Pb}$-supplemented diet was hypothesized to cause growth retardation and accumulation of $\mathrm{Pb}$ on organs and tissues. Therefore, the objective of this 
study was to investigate the influence of dietary $\mathrm{Pb}$ supplementation and feeding period on growth performance, organ weight, and $\mathrm{Pb}$ accumulation in young pigs.

\section{MATERIALS AND METHODS}

\section{Animal care}

The present experiment was reviewed and approved by the Institutional Animal Care and Use Committee of Konkuk University (KU17123).

\section{Animals, diets, and experimental design}

A total of 48 weaned barrows ([Landrace $\times$ Yorkshire $] \times$ Duroc) with an initial body weight (BW) of $10.4 \pm 0.6 \mathrm{~kg}$ were used to investigate the influence of dietary $\mathrm{Pb}$ supplementation on pigs. The animals were allotted to 2 dietary treatments (supplemental $\mathrm{Pb}$ at 0 and $200 \mathrm{mg} / \mathrm{kg}$ as $\mathrm{Pb}$ acetate) in a completely randomized design using a spreadsheet program developed by Kim and Lindemann [11]. To formulate Pb-supplemented diets, the $\mathrm{Pb}$ acetate was supplemented at $366 \mathrm{mg} / \mathrm{kg}$ to make $200 \mathrm{mg} / \mathrm{kg}$ of $\mathrm{Pb}$ (Table 1). Experimental diets were prepared as a 2-phase feeding program (day 0 to 21 and day 21 to 56). The diets were mainly based on corn and soybean meal and were formulated to meet or exceed the nutrient requirement estimates suggested by the NRC [12]. Four pigs were housed in each pen $\left(2.0 \times 2.2 \mathrm{~m}^{2}\right)$ that was equipped with a 2 -hole feeder and a nipple drinker. Pigs had free access to feed and water throughout the experiment.

\section{Data and sample collection}

Individual BW and feed consumption in each pen were recorded every 14 days (on days $0,14,28,42$, and 56 ) to calculate average daily gain (ADG), average daily feed intake (ADFI), and gain to feed ratio (G:F). Individual feed intake of an animal died on day 2 was estimated using the procedure suggested by Lindemann and Kim [13]. On days 14, 28, 42, and 56, an animal randomly selected from each pen was slaughtered to collect blood samples, hair samples, left 5th rib, heart, liver, kidneys, lungs, and longissimus dorsi muscle (LM) samples. Blood samples were collected from the jugular vein with ethylenediaminetetraacetic acid tubes and stored at $4^{\circ} \mathrm{C}$. The organs (heart, liver, kidneys, and lungs) were weighed. The samples except blood were stored in a freezer at $-20^{\circ} \mathrm{C}$. The relative organ weight to $\mathrm{BW}$ was calculated to compensate BW effects.

\section{Chemical analysis}

Diets were finely ground and analyzed for gross energy using a bomb calorimeter (Parr 1261; Parr Instrument Co., Moline, IL, USA). Dry matter (method 930.15), crude protein (method 990.03), ether extract (method 920.39), neutral detergent fiber (method 2002.04), acid detergent fiber (method 973.18), ash
Table 1. Ingredient and analyzed chemical compositions of control diets (as-fed basis)

\begin{tabular}{|c|c|c|}
\hline Item & Day 0 to 21 & Day 21 to 56 \\
\hline \multicolumn{3}{|l|}{ Ingredient (\%) } \\
\hline Ground corn & 58.26 & 62.28 \\
\hline Soybean meal (48\% crude protein) & 24.00 & 33.00 \\
\hline Dried whey & 10.00 & - \\
\hline Fish meal & 3.00 & - \\
\hline Soybean oil & 2.00 & 2.00 \\
\hline L-Lys· HCl (78.8\%) & 0.38 & - \\
\hline DL-Met (99\%) & 0.08 & - \\
\hline L-Thr (99\%) & 0.12 & - \\
\hline Dicalcium phosphate & 0.48 & 1.00 \\
\hline Ground limestone & 0.88 & 0.82 \\
\hline Mineral premix ${ }^{1)}$ & 0.25 & 0.25 \\
\hline Vitamin premix ${ }^{2)}$ & 0.25 & 0.25 \\
\hline Salt & 0.30 & 0.40 \\
\hline \multicolumn{3}{|l|}{ Analyzed composition (\%) } \\
\hline Dry matter & 90.20 & 88.80 \\
\hline Gross energy (kcal/kg) & 4,025 & 4,016 \\
\hline Crude protein & 19.70 & 19.10 \\
\hline Ether extract & 6.49 & 6.09 \\
\hline Ash & 5.17 & 4.74 \\
\hline Calcium & 0.52 & 0.52 \\
\hline Phosphorus & 0.49 & 0.34 \\
\hline Neutral detergent fiber & 7.51 & 8.56 \\
\hline Acid detergent fiber & 2.39 & 2.73 \\
\hline Lead $^{3)}(\mathrm{Pb}, \mathrm{mg} / \mathrm{kg})$ & Not detected & Not detected \\
\hline
\end{tabular}

1) Provided the following quantities per $\mathrm{kg}$ of complete diet: vitamin $\mathrm{A}$, $12,500 \mathrm{IU}$; vitamin $\mathrm{D}_{3}, 1,000 \mathrm{IU}$; vitamin $\mathrm{E}, 125 \mathrm{IU}$; vitamin $\mathrm{K}_{3}, 6.3 \mathrm{mg}$; thiamin, 6.3 mg; riboflavin, 25.0 mg; pyridoxine, 12.5 mg; vitamin $B_{12}, 0.1$ mg; pantothenic acid, $100 \mathrm{mg}$; folic acid, $7.5 \mathrm{mg}$; niacin, $225 \mathrm{mg}$; and biotin, $0.5 \mathrm{mg}$.

2) Provided the following quantities per $\mathrm{kg}$ of complete diet: $\mathrm{Cu}, 87.5 \mathrm{mg}$ as copper sulfate; Fe, $125 \mathrm{mg}$ as iron sulfate; I, $1.0 \mathrm{mg}$ as potassium iodate; $\mathrm{Mn}, 75 \mathrm{mg}$ as manganese sulfate; Se, $0.25 \mathrm{mg}$ as sodium selenite; and $\mathrm{Zn}, 60 \mathrm{mg}$ as zinc oxide.

3) Lead acetate was supplemented at $366 \mathrm{mg} / \mathrm{kg}$ to the control diets to achieve $200 \mathrm{mg} / \mathrm{kg}$ of $\mathrm{Pb}$ in the $\mathrm{Pb}$-supplemented diets. The analyzed $\mathrm{Pb}$ concentrations were 138.6 and $238.5 \mathrm{mg} / \mathrm{kg}$, respectively, during day 0 to 21 and day 21 to 56 .

(method 942.05), calcium (method 978.02), and phosphorus (method 946.06) in the diet were analyzed as described in AOAC [14]. Diet samples were digested [15] and analyzed for $\mathrm{Pb}$ by inductively coupled plasma optical emission spectrometry (Optima 8300; PerkinElmer, Waltham, MA, USA). Lead in blood samples was measured by inductively coupled plasma spectroscopy (Agilent 7900; Agilent Technology, Santa Clara, CA, USA) using a method described by Nunes et al [16]. The left 5th rib, heart, liver, kidneys, lungs, and LM were dried at $105^{\circ} \mathrm{C}$ using an air-forced drying oven. After drying, samples were finely ground. Before digestion, hair samples were cleaned [17]. The left 5th rib was digested as described by Casteel et al [18]. The samples (hair, heart, liver, kidneys, lungs, and LM) were digested and analyzed following the published procedure [19] with minor modification. Briefly, 
weighed samples $(0.2 \mathrm{~g})$ were placed with $2.5 \mathrm{~mL}$ of concentrated $\mathrm{HNO}_{3}$ and $0.5 \mathrm{~mL}$ of concentrated $\mathrm{HCl}$ in a Pyrex glass tube. The tubes packed by a screw cap were kept in a water bath at $85^{\circ} \mathrm{C}$ for $3 \mathrm{~h}$. After digestion, the tubes were kept at room temperature to cool down, and then the digested solution was filtered through a syringe filter with $0.20 \mu \mathrm{m}$ of pore diameter. Each sample was diluted to $50 \mathrm{~mL}$ with double-distilled water in a volumetric flask. The digested samples were analyzed for $\mathrm{Pb}$ by the inductively coupled plasma method (Agilent 7900; Agilent Technology, USA).

\section{Statistical analysis}

Experimental data were analyzed using the MIXED procedure of SAS (SAS Inst. Inc., Cary, NC, USA). Data from a dead pig were excluded in the final calculations and statistical analyses. In the statistical model, only diet was included as the fixed variable for performance data while both diet and feeding period were used as fixed variables for other measurements including organ weight and $\mathrm{Pb}$ concentration in organs and tissues. Least square means of each treatment were calculated. Orthogonal polynomial contrasts were used to test the effects of dietary $\mathrm{Pb}$ supplementation, feeding periods, and the interaction between dietary $\mathrm{Pb}$ supplementation and feeding period. An experimental unit was a pen for growth performance and a pig for organ weight and $\mathrm{Pb}$ concentration in organs and tissues [20]. Statistical significance and tendency were determined at $\mathrm{p}<0.05$ and $0.05 \leq$ $\mathrm{p}<0.10$, respectively.

\section{RESULTS}

During the experimental period, all pigs consumed experimental diets well and remained healthy except that one pig in the control group died on day 2.

The ADG, ADFI, or G:F was not affected by supplemental $\mathrm{Pb}$ during day 0 to 14 and day 14 to 28 (Table 2). However, pigs fed a diet supplemented with $\mathrm{Pb}$ tended to show decreased final BW ( $\mathrm{p}=0.091), \mathrm{ADG}(\mathrm{p}=0.081)$, and ADFI $(\mathrm{p}=0.067)$ during day 28 to 42 compared with those of the control group. Final BW and ADFI were decreased $(\mathrm{p}<0.05)$ by supplemental $\mathrm{Pb}$ during day 42 to 56 . However, dietary $\mathrm{Pb}$ supplementation had no effect on G:F during any period of the experiment.

There was no interaction between dietary $\mathrm{Pb}$ supplementation and feeding period for the weight of heart, liver, kidneys, or lungs (Table 3). However, relative kidney weight to BW was linearly increased with increasing feeding period in pigs fed the $\mathrm{Pb}$-supplemented diet but not in pigs fed the control $\operatorname{diet}(\mathrm{p}<0.05)$.

Table 2. Influence of dietary lead $(\mathrm{Pb})$ supplementation on growth performance of pigs ${ }^{1)}$

\begin{tabular}{|c|c|c|c|c|}
\hline \multirow{2}{*}{ Item } & \multicolumn{2}{|c|}{ Supplemental Pb (mg/kg) } & \multirow{2}{*}{ SEM } & \multirow{2}{*}{ p-value } \\
\hline & 0 & 200 & & \\
\hline \multicolumn{5}{|l|}{ Day 0 to 14} \\
\hline Initial body weight (kg) & 10.28 & 10.49 & 0.12 & 0.226 \\
\hline Final body weight (kg) & 16.60 & 16.21 & 0.42 & 0.526 \\
\hline Average daily gain (g/d) & 451 & 409 & 27 & 0.284 \\
\hline Average daily feed intake (g/d) & 736 & 683 & 33 & 0.289 \\
\hline Gain:feed & 0.612 & 0.599 & 0.022 & 0.702 \\
\hline \multicolumn{5}{|l|}{ Day 14 to 28} \\
\hline Initial body weight (kg) & 16.67 & 16.30 & 0.41 & 0.539 \\
\hline Final body weight (kg) & 24.43 & 23.50 & 0.73 & 0.390 \\
\hline Average daily gain (g/d) & 554 & 514 & 32 & 0.391 \\
\hline Average daily feed intake (g/d) & 1,122 & 1,046 & 33 & 0.139 \\
\hline Gain:feed & 0.494 & 0.490 & 0.020 & 0.907 \\
\hline \multicolumn{5}{|l|}{ Day 28 to 42} \\
\hline Initial body weight (kg) & 24.88 & 23.60 & 0.81 & 0.289 \\
\hline Final body weight (kg) & 35.08 & 31.22 & 1.46 & 0.091 \\
\hline Average daily gain (g/d) & 729 & 545 & 67 & 0.081 \\
\hline Average daily feed intake (g/d) & 1,510 & 1,298 & 73 & 0.067 \\
\hline Gain:feed & 0.480 & 0.406 & 0.038 & 0.199 \\
\hline \multicolumn{5}{|l|}{ Day 42 to 56} \\
\hline Initial body weight (kg) & 34.92 & 30.58 & 1.34 & 0.046 \\
\hline Final body weight (kg) & 44.83 & 39.83 & 1.07 & 0.008 \\
\hline Average daily gain (g/d) & 708 & 661 & 58 & 0.572 \\
\hline Average daily feed intake $(\mathrm{g} / \mathrm{d})$ & 2,144 & 1,626 & 136 & 0.022 \\
\hline Gain:feed & 0.339 & 0.429 & 0.061 & 0.325 \\
\hline
\end{tabular}

SEM, standard error of the means.

1) Each least squares mean represents 6 replicated pens; a pig selected from each pen was slaughtered at the end of each 14-day period. 
Table 3. Influence of dietary lead (Pb) supplementation and feeding period on organ weight of pigs (wet basis)

\begin{tabular}{|c|c|c|c|c|c|c|c|c|c|c|c|c|c|c|}
\hline \multirow{2}{*}{ Item } & \multicolumn{4}{|c|}{0} & \multicolumn{4}{|c|}{200} & \multirow{2}{*}{ SEM } & \multicolumn{5}{|c|}{ p-value ${ }^{1)}$} \\
\hline & 14 & 28 & 42 & 56 & 14 & 28 & 42 & 56 & & $\mathrm{~Pb}$ & $\mathbf{L}$ & $\mathbf{Q}$ & $\mathrm{Pb} \times \mathrm{L}$ & $\mathrm{Pb} \times \mathrm{Q}$ \\
\hline No. of observations & 6 & 5 & 6 & 6 & 6 & 6 & 6 & 6 & & & & & & \\
\hline \multicolumn{15}{|l|}{ Organ weight (g) } \\
\hline Heart & 88 & 129 & 170 & 210 & 87 & 127 & 145 & 189 & 9 & 0.048 & $<0.001$ & 0.952 & 0.133 & 0.816 \\
\hline Liver & 479 & 627 & 887 & 1,033 & 422 & 580 & 744 & 923 & 40 & 0.002 & $<0.001$ & 0.867 & 0.295 & 0.836 \\
\hline Kidneys & 81 & 116 & 173 & 219 & 81 & 134 & 180 & 254 & 10 & 0.035 & $<0.001$ & 0.247 & 0.127 & 0.691 \\
\hline Lungs & 193 & 259 & 353 & 448 & 196 & 303 & 344 & 399 & 34 & 0.904 & $<0.001$ & 0.805 & 0.323 & 0.395 \\
\hline \multicolumn{15}{|c|}{ Organ weight relative to body weight ${ }^{2)}(\%)$} \\
\hline Heart & 0.54 & 0.56 & 0.49 & 0.47 & 0.54 & 0.55 & 0.45 & 0.47 & 0.02 & 0.583 & $<0.001$ & 0.661 & 0.800 & 0.317 \\
\hline Liver & 2.92 & 2.72 & 2.52 & 2.30 & 2.65 & 2.52 & 2.36 & 2.31 & 0.10 & 0.028 & $<0.001$ & 0.800 & 0.142 & 0.715 \\
\hline Kidneys & 0.49 & 0.50 & 0.49 & 0.49 & 0.51 & 0.58 & 0.57 & 0.64 & 0.03 & $<0.001$ & 0.074 & 0.880 & 0.037 & 0.856 \\
\hline Lungs & 1.18 & 1.14 & 1.01 & 1.00 & 1.23 & 1.33 & 1.08 & 1.00 & 0.10 & 0.246 & 0.010 & 0.617 & 0.664 & 0.470 \\
\hline
\end{tabular}

SEM, standard error of the means.

1) $\mathrm{Pb}$, dietary Pb supplementation; $\mathrm{L}$, linear effect of feeding period; $\mathrm{Q}$, quadratic effect of feeding period; $\mathrm{Pb} \times \mathrm{L}$, interaction between dietary Pb supplementation and linear effect of feeding period; $\mathrm{Pb} \times \mathrm{Q}$, interaction between dietary $\mathrm{Pb}$ supplementation and quadratic effect of feeding period.

2) Relative organ weights to body weight $(\%)=$ organ weight $(\mathrm{kg}) /$ body weight of pig $(\mathrm{kg}) \times 100$.

Supplemental $\mathrm{Pb}$ at $200 \mathrm{mg} / \mathrm{kg}$ resulted in increased $\mathrm{Pb}$ concentrations $(\mathrm{p}<0.01)$ in hair, 5th rib, blood, liver, kidneys, lungs, and LM of pigs (Table 4). In pigs fed the Pb-supplemented diet, $\mathrm{Pb}$ concentrations in hair, 5th rib, kidneys, and lungs were linearly increased with longer feeding period but not in pigs fed the control diet $(\mathrm{p}<0.01)$, indicating the interaction between dietary $\mathrm{Pd}$ and linear effects of feeding period. The $\mathrm{Pb}$ concentration in liver was quadratically increased with longer feeding period in pigs fed the $\mathrm{Pb}$-supplemented diet, but not in pigs fed the control diet $(\mathrm{p}<0.01)$, indicating the interaction between dietary Pd and quadratic effects of feeding period.
When $\mathrm{Pb}$ weight in organs were calculated, supplemental $\mathrm{Pb}$ resulted in greater $(\mathrm{p}<0.01) \mathrm{Pb}$ weight in liver, kidneys, and lungs. In the $\mathrm{Pb}$-supplemented group, the $\mathrm{Pb}$ weight in liver, kidneys, and lungs were linearly increased with longer feeding period but not in the control group $(\mathrm{p}<0.05)$.

\section{DISCUSSION}

The present work revealed that growth performance of pigs fed the $\mathrm{Pb}$-supplemented diet was reduced compared with that of pigs fed the control diet, in agreement with results in previous studies [21,22]. However, some researchers failed

Table 4. Influence of dietary lead (Pb) supplementation and feeding period on Pb concentration of pig organs (wet basis except for hair)

\begin{tabular}{|c|c|c|c|c|c|c|c|c|c|c|c|c|c|c|c|}
\hline \multirow{2}{*}{ Item } & \multirow{2}{*}{$\frac{\mathrm{Pb}(\mathrm{mg} / \mathrm{kg})}{\text { Period (d): }}$} & \multicolumn{4}{|c|}{0} & \multicolumn{4}{|c|}{200} & \multirow{2}{*}{ SEM } & \multicolumn{5}{|c|}{ p-value ${ }^{1)}$} \\
\hline & & 14 & 28 & 42 & 56 & 14 & 28 & 42 & 56 & & $\mathrm{~Pb}$ & $\mathbf{L}$ & $\mathbf{Q}$ & $\mathrm{Pb} \times \mathrm{L}$ & $\mathrm{Pb} \times \mathrm{Q}$ \\
\hline \multicolumn{2}{|c|}{ No. of observations } & 6 & 5 & 6 & 6 & 6 & 6 & 6 & 6 & & & & & & \\
\hline \multicolumn{2}{|c|}{ Hair (mg/kg) } & 1.42 & 0.92 & 1.47 & 1.36 & 4.35 & 9.15 & 17.63 & 26.23 & 2.06 & $<0.001$ & $<0.001$ & 0.460 & $<0.001$ & 0.547 \\
\hline \multicolumn{2}{|c|}{ Left 5th rib (mg/kg) } & 3.58 & 1.64 & 1.68 & 1.90 & 44.58 & 42.68 & 100.58 & 149.03 & 9.35 & $<0.001$ & $<0.001$ & 0.046 & $<0.001$ & 0.066 \\
\hline \multicolumn{2}{|c|}{ Blood $(\mu \mathrm{g} / \mathrm{dL})$} & 0.013 & 0.007 & 0.003 & 0.003 & 0.378 & 0.582 & 0.454 & 0.521 & 0.031 & $<0.001$ & 0.178 & 0.059 & 0.089 & 0.042 \\
\hline \multicolumn{16}{|c|}{$\mathrm{Pb}$ concentration in fresh tissue $\mathrm{e}^{2)}(\mathrm{mg} / \mathrm{kg})$} \\
\hline \multicolumn{2}{|c|}{ Heart } & 0.60 & 0.70 & 0.92 & 0.59 & 0.81 & 0.83 & & & 0.17 & 0.206 & 0.286 & & & 0.027 \\
\hline \multicolumn{2}{|c|}{ Liver } & 0.27 & 0.49 & 0.65 & 1.06 & 10.49 & 6.99 & 8.64 & 12.14 & 0.74 & $<0.001$ & 0.047 & 0.001 & 0.368 & 0.002 \\
\hline \multicolumn{2}{|c|}{ Kidneys } & 0.50 & 0.23 & 0.17 & 0.20 & 7.95 & 7.03 & 8.89 & 10.09 & 0.44 & 01 & 0.008 & 49 & 01 & .132 \\
\hline \multicolumn{2}{|c|}{ Lungs } & 0.21 & 0.10 & 0.10 & 0.07 & 0.27 & 0.31 & 0.37 & 0.36 & 0.04 & $<0.001$ & 0.780 & 0.857 & 0.002 & 0.245 \\
\hline \multicolumn{2}{|l|}{ LM } & 0.14 & 0.20 & 0.13 & 0.24 & 0.30 & 0.26 & 0.27 & 0.25 & 0.03 & $<0.001$ & 0.663 & 0.437 & 0.100 & 0.715 \\
\hline \multicolumn{16}{|c|}{$\mathrm{Pb}$ weight in fresh organ (mg) } \\
\hline \multicolumn{2}{|c|}{ Heart } & 0.05 & 0.09 & 0.16 & 0.12 & 0.07 & 0.11 & 0.09 & 0.23 & 0.03 & 0.433 & $<0.001$ & 0.675 & 0.305 & 0.026 \\
\hline \multicolumn{2}{|c|}{ Liver } & 0.13 & 0.31 & 0.57 & 1.11 & 4.46 & 4.04 & 6.60 & 11.27 & 0.61 & $<0.001$ & $<0.001$ & 0.002 & $<0.001$ & 0.007 \\
\hline \multicolumn{2}{|c|}{ Kidneys } & 0.04 & 0.03 & 0.03 & 0.04 & 0.64 & 0.94 & 1.65 & 2.59 & 0.13 & $<0.001$ & $<0.001$ & 0.065 & $<0.001$ & 0.087 \\
\hline \multicolumn{2}{|c|}{ Lungs } & 0.04 & 0.03 & 0.04 & 0.03 & 0.05 & 0.09 & 0.15 & 0.15 & 0.02 & $<0.001$ & 0.022 & 0.559 & 0.012 & 0.444 \\
\hline
\end{tabular}

LM, longissimus dorsi muscle; SEM, standard error of the means.

1) $\mathrm{Pb}$, dietary $\mathrm{Pb}$ supplementation; $\mathrm{L}$, linear effect of feeding period; $\mathrm{Q}$, quadratic effect of feeding period; $\mathrm{Pb} \times \mathrm{L}$, interaction between dietary $\mathrm{Pb}$ supplementation and linear effect of feeding period; $\mathrm{Pb} \times \mathrm{Q}$, interaction between dietary $\mathrm{Pb}$ supplementation and quadratic effect of feeding period.

${ }^{2}$ The values were calculated based on the $\mathrm{Pb}$ concentrations in dried organ and moisture concentration in fresh organ. 
to find the negative effects of dietary $\mathrm{Pb}$ on growth performance of pigs $[23,24]$. The lack of responses in performance was likely due to the low concentration of dietary $\mathrm{Pb}$, short experimental period, or both. While dietary $\mathrm{Pb}$ concentration was $200 \mathrm{mg} / \mathrm{kg}$ in the present work, in the study by Zacharias et al [24], the $\mathrm{Pb}$ concentration in the experimental diet was $1.45 \mathrm{mg} / \mathrm{kg}$ and feed intake was restricted. The feeding period might be another factor that influences performance responses to dietary $\mathrm{Pb}$. Although the $\mathrm{Pb}$ concentration was $250 \mathrm{mg} / \mathrm{kg}$ in the study of Reddy et al [23], the feeding period was only 28 days.

The increased kidney weight by dietary $\mathrm{Pb}$ supplementation in the present work agrees with results of previous studies using rats and mice $[25,26]$. Urinary excretion of absorbed $\mathrm{Pb}$ is one of major $\mathrm{Pb}$ excretion routes, which indicates that kidneys are target organs for $\mathrm{Pb}$ toxicity [26]. In rats, supplemental $\mathrm{Pb}$ can reduce the concentration of glutathione and antioxidant enzymes [25] but increase cell proliferation in the proximal tubular epithelium of the kidney [27]. These effects of $\mathrm{Pb}$ toxicity on the kidney may be a major reason for the increased kidney weight in the $\mathrm{Pb}$-supplemented group observed in the present work.

While the absorption rate of $\mathrm{Pb}$ is less than other heavy metals such as copper or mercury, $\mathrm{Pb}$ is relatively slowly excreted from animals. Therefore, $\mathrm{Pb}$ is accumulated well in most tissues once absorbed into animal body [10]. Previous studies have reported that $\mathrm{Pb}$ is highly accumulated in bone, kidneys, liver, and hair [21,22], but not in muscle [24,28], which agrees with the present study.

In $\mathrm{Pb}$ toxicity experiments, the $\mathrm{Pb}$ concentration and feeding period are important factors. In the present work, only 2 concentrations ( 0 and $200 \mathrm{mg} / \mathrm{kg}$ ) of $\mathrm{Pb}$ were used, making it impossible to assess dose-dependent polynomial effects. However, 4 feeding periods (14, 28, 42, and 56 days) were employed and time-dependent effects of dietary $\mathrm{Pb}$ were observed. In agreement, previous studies reported that $\mathrm{Pb}$ concentrations in organs were increased as the feeding period was increased to 84 days in rats [29] and pigs [28]. In rats, $\mathrm{Pb}$ concentrations in tissues were increased with increasing $\mathrm{Pb}$ intake and the total amount of $\mathrm{Pb}$ in tissue did not affect absorption of $\mathrm{Pb}$ [9], which indicates that animals perhaps do not regulate $\mathrm{Pb}$ absorption or excretion. Although no data are available on $\mathrm{Pb}$ absorption or excretion in pigs, the increased $\mathrm{Pb}$ concentrations in pig organs and tissues, particularly in bone, hair, and kidneys, by extended feeding of $\mathrm{Pb}$ in the present work were likely due to the inability of pigs for excreting absorbed $\mathrm{Pb}$. Lead elimination rate in bone is less than that in other tissues in rats [9] and pigs [28], which explains the greatest $\mathrm{Pb}$ accumulation in bone and the linear response of $\mathrm{Pb}$ concentration with increasing exposure time in the present work.

The quadratic increase of $\mathrm{Pb}$ concentration in organs with longer feeding period may be associated with the age of animals and a dietary milk product. Sharma et al [28] have reported that $\mathrm{Pb}$ is more highly accumulated in $30-\mathrm{kg}$ pigs than in $50-\mathrm{kg}$ pigs. Similarly, as the age of rats increased, the absorption of $\mathrm{Pb}$ decreased $[9,30]$. In the present work, $\mathrm{Pb}$ was more highly accumulated in pigs likely due to the young age during the first few weeks. Dietary lactose is also a factor that influences the absorption of $\mathrm{Pb}$. In rats, dietary $\mathrm{Pb}$ was more highly accumulated in organs when a lactose-added diet was provided compared with a glucose-added diet [30]. Bell and Spickett [31] have also reported that dietary $\mathrm{Pb}$ is more efficiently accumulated in rats fed a dried whole milk diet which contains an appreciable amount of lactose than those fed a lactose-hydrolyzed milk diet. In the present work, dried whey containing lactose was included at $10 \%$ in the experimental diets during the first 3 weeks. Dietary lactose may be a potential reason for the relatively high $\mathrm{Pb}$ concentrations in the day 14 samples of bone, liver, and kidneys of pigs fed a $\mathrm{Pb}$-supplemented diet.

The linear response of $\mathrm{Pb}$ weight in the liver, kidneys, and lungs by dietary $\mathrm{Pb}$ supplementation is mainly due to the $\mathrm{Pb}$ concentrations rather than organ weights that were affected by dietary $\mathrm{Pb}$. The organ $\mathrm{Pb}$ weight was calculated by multiplying $\mathrm{Pb}$ concentration by organ weight, which represents the amount of $\mathrm{Pb}$ accumulated in the organs. The present results indicate that the concentrations of $\mathrm{Pb}$ in the organs sufficiently represent the accumulation of $\mathrm{Pb}$ in organs.

\section{CONCLUSION}

Dietary $\mathrm{Pb}$ supplementation can cause growth retardation and increase kidney weight with an increasing feeding period. In addition, when duration of dietary $\mathrm{Pb}$ exposure was increased, the $\mathrm{Pb}$ concentration was increased in organs and tissues, although its accumulation rates varied depending on organs and tissues of pigs. Lead was accumulated particularly in hair, bone, and kidneys in a time-dependent manner.

\section{CONFLICT OF INTEREST}

We certify that there is no conflict of interest with any financial organization regarding the material discussed in the manuscript.

\section{ACKNOWLEDGMENTS}

The authors are grateful for the support by Rural Development Administration (Republic of Korea; PJ010932).

\section{REFERENCES}

1. Lockitch G. Perspectives on lead toxicity. Clin Biochem 1993; 
26:371-81. https://doi.org/10.1016/0009-9120(93)90113-K

2. Brams E, Anthony W. Cadmium and lead through an agricultural food chain. Sci Total Environ 1983;28:295-306. https:// doi.org/10.1016/S0048-9697(83)80027-8

3. Doyle JJ, Spaulding JE. Toxic and essential trace elements in meat - a review. J Anim Sci 1978;47:398-419. https://doi.org/ 10.2527/jas1978.472398x

4. Gurer H, Ercal N. Can antioxidants be beneficial in the treatment of lead poisoning? Free Radic Biol Med 2000;29:92745. https://doi.org/10.1016/S0891-5849(00)00413-5

5. Mertz W. Trace elements in human and animal nutrition. 5th ed. Orlando, FL, USA: Academic Press; 1986.

6. Tariq H, Sharma A, Sarkar S, Ojha L, Pal RP, Mani V. Perspectives for rare earth elements as feed additive in livestock - a review. Asian-Australas J Anim Sci 2020;33:373-81. https:// doi.org/10.5713/ajas.19.0242

7. National Research Council. Mineral tolerance of animals. 2nd ed. Washington, DC, USA: National Academies Press; 2005.

8. Council of the European Union. Directive 2002/32/EC of the European Parliament and of the Council of 7 May 2002 on undesirable substances in animal feed. Off J Eur Union 2002;140:10-22.

9. Conrad ME, Barton JC. Factors affecting the absorption and excretion of lead in the rat. Gastroenterology 1978;74:73140. https://doi.org/10.1016/0016-5085(78)90253-6

10. Humphreys DJ. Effects of exposure to excessive quantities of lead on animals. Br Vet J 1991;147:18-30. https://doi.org/10. 1016/0007-1935(91)90063-S

11. Kim BG, Lindemann MD. A spreadsheet method for experimental animal allotment. J Anim Sci 2007;85(Suppl 2):112.

12. Committee on Nutrient Requirements of Swine, National Research Council. Nutrient requirements of swine. 11th ed. Washington, DC, USA: National Academies Press; 2012.

13. Lindemann MD, Kim BG. Technical note: a model to estimate individual feed intake of swine in group feeding. J Anim Sci 2007;85:972-5. https://doi.org/10.2527/jas.2006-412

14. Horwitz W, Latimer GW. AOAC International. Official methods of analysis of AOAC International. 18th ed. Gaithersburg, MD, USA: AOAC International; 2005.

15. Wu S, Feng X, Wittmeier A. Microwave digestion of plant and grain reference materials in nitric acid or a mixture of nitric acid or a mixture of nitric acid and hydrogen peroxide for the determination of multi-elements by inductively coupled plasma mass spectrometry. J Anal At Spectrom 1997;12:797806. https://doi.org/10.1039/A607217H

16. Nunes JA, Batista BL, Rodrigues JL, Caldas NM, Neto JAG, Barbosa F. A simple method based on ICP-MS for estimation of background levels of arsenic, cadmium, copper, manganese, nickel, lead, and selenium in blood of the Brazilian population. J Toxicol Environ Health A 2010;73:878-87. https://doi.org/ $10.1080 / 15287391003744807$
17. Chaturvedi R, Banerjee S, Chattopadhyay P, Bhattacharjee CR, Raul P, Borah K. High iron accumulation in hair and nail of people living in iron affected areas of Assam, India. Ecotoxicol Environ Saf 2014;110:216-20. https://doi.org/10. 1016/j.ecoenv.2014.08.028

18. Casteel SW, Weis CP, Henningsen GM, Brattin WJ. Estimation of relative bioavailability of lead in soil and soil-like materials using young swine. Environ Health Perspect 2006;114:116271. https://doi.org/10.1289/ehp.8852

19. Ashoka S, Peake BM, Bremner G, Hageman KJ, Reid MR. Comparison of digestion methods for ICP-MS determination of trace elements in fish tissues. Anal Chim Acta 2009;653: 191-9. https://doi.org/10.1016/j.aca.2009.09.025

20.Seo S, Jeon S, Ha JK. Guidelines for experimental design and statistical analyses in animal studies submitted for publication in the Asian-Australasian Journal of Animal Sciences. AsianAustralas J Anim Sci 2018;31:1381-6. https://doi.org/10.5713/ ajas. 18.0468

21. Hsu FS, Krook L, Pond WG, Duncan JR. Interactions of dietary calcium with toxic levels of lead and zinc in pigs. J Nutr 1975; 105:112-8. https://doi.org/10.1093/jn/105.1.112

22.Phillips C, Győri Z, Kovács B. The effect of adding cadmium and lead alone or in combination to the diet of pigs on their growth, carcass composition and reproduction. J Sci Food Agric 2003;83:1357-65. https://doi.org/10.1002/jsfa.1548

23. Reddy KE, Park KR, Lee SD, Yoo JH, Son AR, Lee HJ. Effects of graded concentrations of supplemental lead on lead concentrations in tissues of pigs and prediction equations for estimating dietary lead intake. Peer J 2017;5:e3936. https:// doi.org/10.7717/peerj.3936

24.Zacharias B, Lantzsch HJ, Drochner W. Influence of microbial phytase and dietary calcium on the accumulation of lead in different organs of pigs. Biol Trace Elem Res 1999;70:243. https://doi.org/10.1007/BF02783833

25.Abdel-Moneim AE, Dkhil MA, Al-Quraishy S. The potential role of flaxseed oil on lead acetateinduced kidney injure in adult male albino rats. Afr J Biotechnol 2011;10:1436-51.

26. Mohammadi S, Zamani E, Mohadeth Z, et al. Effects of different doses of simvastatinon lead-induced kidney damage in Balb/c male mice. Pharm Sci 2015;20:157-62.

27. Choie DD, Richter GW. Cell proliferation in rat kidney induced by lead acetate and effects of uninephrectomy on the proliferation. Am J Pathol 1972;66:265-76.

28. Sharma RP, Street JC, Shupe JL. Translocation of lead and cadmium from feed to edible tissues of swine. J Food Saf 1982;4:151-63. https://doi.org/10.1111/j.1745-4565.1982. tb00439.x

29. Areola OO, Jadhav AL, Williams-Johnson M. Relationship between lead accumulation in blood and soft tissues of rats subchronically exposed to low levels of lead. Toxic Subst Mech 1999;18:149-61. https://doi.org/10.1080/107691899229115

30. Bushnell PJ, DeLuca HF. The effects of lactose on the absorp- 
tion and retention of dietary lead. J Nutr 1983;113:365-78. https://doi.org/10.1093/jn/113.2.365

31.Bell RR, Spickett JT. The influence of milk in the diet on the toxicity of orally ingested lead in rats. Food Cosmet Toxicol 1981;19:429-36. https://doi.org/10.1016/0015-6264(81)90 446-6 